\title{
The Role of Religiosity and Spiritual Meaningfullness towards Cyberbullying Behavior
}

\author{
Triantoro Safaria \\ Faculty of Psychology \\ University Ahmad Dahlan \\ triantoro.safaria@psy.uad.ac.id
}

\author{
Khoiruddin Bashori \\ Faculty of Psychology \\ University Ahmad Dahlan \\ khoiruddin.bashori@psy.uad.ac.id
}

\begin{abstract}
Several previous studies have explained that cyberbullying has a negative impact on the victim. Currently, there are no research findings that examine the relationship between religiosity and spiritual meaning with cyberbullying. The current study is conducted to answer the gap of existing knowledge. The purpose of this study is to examine the relationship between religiosity and spiritual meaning with cyberbullying behavior. The research sample the students from a private university in Yogyakarta totaling 152 people (74 (49.3\%) male; 76 (50.7\%) female) who were taken by purposive sampling technique. Three questionnaires were used to collect the data. Regression analysis was implemented. The results of this study indicated that there is a very significant relationship between religiosity and spiritual meaningfulness with cyberbullying behavior. The implication of this research is to emphasize the role of religiosity and spiritual meaning for adolescents to prevent cyberbullying behavior.
\end{abstract}

Keywords: Religiosity, spiritual meaning, and cyberbullying behavior

Received I April 202I/Accepted 7 June 202I @Author all rights reserved

\section{Introduction}

Cyberbullying is any aggressive behavior that insults, humiliates, and threatens others over the internet by an individual or group of people repeatedly with the aim of hurting, insulting, and causing discomfort to others (Peter \& Petermann, 2018; Barlett, \& Chamberlin, 20I7; Zych, Ortega-Ruiz, \& Del Rey, 20I5; Tokunaga, 20I0). Cyberbullying is an act of bullying that is carried out in cyberspace, via the internet. In general, many teenagers experienced cyberbullying victimization through their social media (Safaria, 2016; Safaria, Tentama, \& Suyono, 2016; Ang, 2015). 
Safaria's study (2016a) found out from 102 junior high school students, 14.28\% (14) had never been victims of cyberbullying, $25.5 \%$ (26) had experienced one or two times, $20.6 \%$ (2I) were victims of cyberbullying two to three times , $27.5 \%$ (28) have been victims four to five times. The remaining $12.7 \%$ (I3) experienced cyberbullying on an almost daily basis. From the available data, it is concluded that $80 \%$ of respondents have been victims of cyberbullying from twice to almost every day. Currently cyberbullying has become a common phenomenon throughout the world (Leung, Wong, \& Farver, 2018; Sung Hong et al., 2018; Safaria , 2016, Safaria, Tentama, \& Suyono, 2016; Ang, 2015). The results of previous studies showed that the prevalence rate of cyberbullying ranges from $2 \%$ to $35 \%$ (Kowalski et al., 20l4; Låftman et al., 2013). Meanwhile, looking at the incidence of cyberbullying in several countries shows a disturbing phenomenon. In China the prevalence was 34.84\% (Zhou et al., 20I3) in Canada was I0\% (Cappadocia et al., 20I3) and in Sweden was5\% (Låftman et al., 2013).

Several previous studies have shown cyberbullying victimization correlates with alcohol dependence, marijuana used, deviant health risk behaviors, suicidal tendencies and frequency of unhealthy sexual behavior (Peled, 2019; Graham \& Brailovskaia, Teismann, \& Margraf, 2018; Watts, et al., 2017). Furthermore, the combination of physical bullying and cyberbullying produces a heavier impact on deviant risk behavior (Graham \& Wood, 2018). Cyberbullying victimization also correlates with the idea of suicide/suicide (Brailovskaia, Teismann, \& Margraf, 2018), as well as symptoms of depression (Sung Hong et al, 2018). Gradinger, Strohmeier, and Spiel (2009) found that victims of cyberbullying have poor selfadjustment such as depression, somatic symptoms, and aggressive behavior. Research by Baker and Tanrikulu (2010) also found symptoms of depression among adolescent of cyberbullying victims. However, the occasional cyberbullying victimization has a lower negative psychological impact than a continuous one (Tokunaga, 20l0).

Previous research has found several factors that influence cyberbullying behavior, including gender, personality type, empathy, emotional intelligence (Sung Hong et al., 2018; Lee, \& Shin, 2017; Ang, \& Goh, 20I0; Balakrishnan, 2015), one that still needs to be tested further is the role of religiosity and spirituality meaningfulness. Sheldrake (20/3) defines spirituality as a conscious involvement in the process of integrating life through self-transcendence towards 
the Almighty that is believed by individuals. Meanwhile, Thorensen (1998) defines spirituality as a transcendent relationship between a person and an Almighty substance. Spirituality is not exclusively owned by a particular religion, so spirituality is not a religion. Other experts state that spirituality is connected to broader ideas, which give meaning to life and the development of self-awareness (Horton, Luna, \& Malloy, 2016; Zych, I., Ortega-Ruiz, R., Del Rey, R. 2015). Meanwhile, religiosity has a more specific dimension, and is defined as an organized system of beliefs, practices, rituals and symbols that are believed by individuals (Thorensen, 1998). It can be concluded that spirituality includes broader aspects and dimensions, compared to religiosity which refers to the obedience and faith of individuals to their religious teachings. Meanwhile, meaningfulness means achieving meaning and positive values in an individual's life (Frankl, 1977). Spiritual meaning can then be concluded with the spiritual meaningfulness of the individual in his or her life.

According to Frankl (1977), the symptoms of a person who has lost the meaning of his life are shown by feeling empty, feeling that life is meaningless, feeling that they do not have a clear purpose in life, boredom and apathy. These symptoms are the result of not fulfilling the source of the meaning of life in humans. Living life without meaning may not seem real, but it is hidden behind various compensation efforts and excessive will to power (the will to power), having fun looking for pleasure (the will to pleasure), including seeking sexual pleasure (the will to sex), working (the will to work), and collecting as much money as possible (the will to money).

Previous studies related to religiosity and spirituality has shown that religious adolescents have a lower risk of engaging in negative behaviors such as cyberbullying, gambling, alcohol and drug use, and free sex (Kinanti, \& Hartati, 2017; Debnam, et al, 2017; Landor, Simons, Gibbons, Simons, \& Brody, 20II; Casey, et al, 20ll). Research on cyberbullying which is associated with religiosity and spiritual meaning has not been carried out either in Indonesia or abroad (Arianti, Anggraini, Paryati, \& Fatimah, 2020; Kinanti, \& Hartati, 2017). How the process of cyberbullying occurs, and how religiosity and spiritual meaning are related to cyberbullying behavior is not yet known in a sample of adolescents in Indonesia. This is important because accurate information about how cyberbullying occurs will be very useful for the government, schools, teachers and parents. This is mainly used as a basis for 
developing preventive programs to deal with bullying behavior among adolescents. The purpose of this study was to examine the role of religiosity and spiritual meaningfulness with cyberbullying behavior. The hypothesis proposed in this study are as follows:

- There is a significant relationship between religiosity and spiritual meaningfulness with cyberbullying behavior.

- There is a significant relationship between religiosity and cyberbullying behavior.

- There is a significant relationship with spiritual meaning and cyberbullying behavior.

\section{Method}

Design

This research is a quantitative study with a cross-sectional approach by taking data only at one time.

\section{Respondents}

Respondents of this study have the following characteristics, namely students at a private university in Yogyakarta totaling 152 people. Male (49.3\%) and female (50.7\%), and aged between 13-20 years. The sampling technique used in this study was purposive sampling based on certain criteria. Criteria for this study sample were male and female, aged 19-22 years, and had the status of a student. Information about informed consent was given before respondents were involved in this study, so that the involvement of respondents was voluntary.

\section{Data analysis}

To test the hypothesis proposed in this study, a quantitative data analysis technique using regression analysis was used to test whether the predictor variable contributed to the criterion variable. The data were processed using the statistical program SPSS 16. 


\section{Measurement}

The scales of cyberbullying, religiosity, and spiritual meaning were used to collect the data. This scale as a research measure, before used, was tested for its validity and reliability. The content validity and reliability of Cronbach alpha were conducted in this study.

Cyberbullying. Willard's theory is used as a blue print in the questionnaire, that consisting of seven forms, namely Flaming, Online Harassment, cyberstalking, denigration, masquerade, outing and exclusion(Willard, 2007). The four responses implemented that consisting of frequently, sometimes, rarely, and never. Examples of items such as "I purposely sent insulting messages to someone else's account", "I spread someone's personal secret on social media." The alpha-Cronbach coefficient of this scale is $=0.966$.

Religiousity. The religiosity scale used Glock and Stark's (1965) theory which consists of five dimensions or aspects of religiosity, namely the ideological dimension (religious belief), the ritualistic dimension (religious practice), the experiential dimension (religious feeling or experiential dimension), the consequential dimension (religious). effect). An example of an item on this scale is "I believe in the teachings of my religion" "I am diligent in praying and other worship" "I avoid sin". Cronbach's coefficient of alphas-scale religiosity $=0.695$.

Spiritual meaningfulness. The spiritual meaningful scale was developed based on the theory of Pargament (2007). There are four responses that are very suitable, appropriate, inappropriate, very inappropriate. An example of an item is "I feel a deep spiritual meaning in my life" "I feel a strong connection with the creator" "I feel my life is meaningful because of my spiritual beliefs". The cronbach alpha coefficient of this scale $=0.844$.

\section{Results}

The results of this study indicate that religiosity has a very significant positive relationship to cyberbullying behavior $(\beta=, 817, p=.000)$. The results of this study also show that spiritual meaningfulness has a very significant negative relationship with cyberbullying behavior $(\beta=-$. $588, \mathrm{p} .=.000)$ Table I presents the results of the regression analysis. 
Table I

Regression result of religiosity, spiritual meaningfullness with cyberbullying behavior

\begin{tabular}{lllccc}
\hline \multicolumn{1}{c}{ Variable } & B & SEB & $\beta$ & $t$ & $P$ \\
\hline Religiosity & $\mathrm{I} .388$ & .138 & .817 & 10,085 &, 000 \\
Spiritual & -.864 & .119 & -.588 & $-7,261$ &, 000 \\
\hline
\end{tabular}

Note. $R^{2}=.409(N=152, p=.000)$.

Meanwhile, the mean, standard deviation, and correlation between variables are presented in Table 2 below.

Table 2

Means, Standard Deviations, and Intercorrelations variable

\begin{tabular}{lccccc}
\hline Measure & M & SD & I & 2 & 3 \\
\cline { 2 - 5 } Cyberbullying & 10,8 & 3,3 & 1.000 & & \\
Religiosity & 23,4 & 1,9 &, 447 & 1.000 & \\
Spiritual & 20,7 & 2,3 &,- 074 &, 629 & 1.000 \\
\hline
\end{tabular}

\section{Discussion}

The results of this study indicate that there is a significant positive relationship between religiosity and cyberbulling behavior. This study contradicts several previous studies that found a significant negative relationship, such as the research by Kinanti and Hartati (2017) which found a significant negative relationship between extrinsic and intrinsic religious orientation and intention cyberbullying. Likewise, research by Arianti, Anggraini, Paryati, \& Fatimah (2020) found a significant negative relationship between religiosity and cyberbullying behavior in adolescents. The current findings of this research are also inconsistent with several previous studies that show religiosity is negatively correlated with juvenile delinquency and health risk behavior (Barton et al., 20I4; Klanjsek et al., 20I2; Baier \& Wright, 200I).

Theoretically, the relationship between religiosity and cyberbullying behavior should be negatively correlated, where when religiosity is high, the cyberbullying behavior is low, and 
vice versa. In the perspective of the social control framework (Hirschi, 1969), family and religion are institutions that exercise social control for individuals through the socialization process of its members to adopt conventional norms and values that must be obeyed by individuals (Baier, \& Wright, 200I; Sherkat, \& Ellison, 1999). Simultaneously with the process of socializing these values and norms, there will be an internalization process within the individual, so that it will then form a pattern of personality and behavior, so that it is in accordance with the values and norms he believes in. This will directly foster commitment and conformity to these social values and norms (Barton et al, 2014; Smith, 2003), thereby preventing individuals from engaging in deviant behavior, such as free sex, gambling and cyberbullying behavior (Safaria, \& Suyono, 2020; Casey, et al., 201I; Landor, Simons, Gibbons, Simons, \& Brody, 20II). It can be concluded that the current research findings contradict the theory and some previous research. Why could this happen? The possibility occurs due to the internalization process of the religion values only on the surface, not deeply comprehens, this lead to low effect for changing individual behavior. The new religiosity behavior in the form of abrogating obligations, such as prayer, fasting, may not be able to control individual behavior in a better direction. Moreover, the respondents of this study were adolescents, each of whom being strive to find their identity, their attitudes and behavior, their religion values, and still impulsive, and cannot think in a mature.

This study also found spiritual meaning to have a significant negative relationship to bullying behavior. The findings of this study confirm previous research such as research by Yadav \& Yadav (2018) which found a significant negative relationship between spirituality and cyberbullying behavior. Research by Dutkova et al. (2017) found a significant negative relationship between spirituality and bullying behavior. Several previous studies have also found spirituality reduces risky behavior (Sinha, 20I2; VonDras et al. 2007; Pirutinsky, 20I4; Pickering, \& Vazsonyi, 2010; McCullough, \& Willoughby, 2009; Baier, \& Wright, 200I) such as smoking, and drinking alcoholic beverages. Other studies (Davis et al. 2003; Cotton et al. 2005; Koenig, Al Zaben, \& Khalifa, 2012; Greenfield et al. 2007) found spiritual well-being reduces anxiety, anger, depression, and frustration which are closely related to bullying behavior. 
Spirituality helps person to form and develop existensial meaning, belief in the existence of the Creator, more compassion to the self and others. This belief provides and creates adequate emotional calm and the ability for deep self-reflection (Yadav \& Yadav, 20I8; Carone \& Barone, 200I). Better understanding of the existensial meaning provides inner peace to the individual, that lead to more care for others. Spiritual meaning makes individuals understand life more wisely, have compassion for fellow human beings, more patient in dealing with negative situations, and have a deep sense of empathy. Achieving a spiritual meaning prevents individuals easly to hurt others, such as cyberbullying behavior.

\section{Conclusion}

The results of this study indicate that religiosity and spiritual meaning have a role in cyberbullying behavior in adolescents, especially college students. Religiosity in this study has a positive correlation with cyberbullying behavior, so this result is contrary to some previous studies. Suggestions for further research are that it is necessary to add other variables which are hypothesized to play a role in the occurrence of cyberbullying. It is recommended that the future study consider a larger number of samples in order to be more representative of population.

\section{References}

Ang, R.P., \& Goh, D.H. (2010). Cyberbullying among adolescents: The role of affective and cognitive empathy, and gender. Child Psychiatry Hum Dev,4I, 387-397.

Arianti, F. P., Anggraini, A. N., Paryati, T., \& Fatimah (2020). Hubungan religiusitas dengan perilaku cyberbullying pada remaja SMP I 2 Yogyakarta. Laporan penelitian. Universitas Alma Alta. Yogyakarta

Baier, C. J., \& Wright, B. R. (200 I). If you love me, keep my commandments: A meta-analysis of the effect of religion on crime. Journal of Research in Crime and Delinquency, 38, 3-2I.

Balakrishnan, V. (20I5). Cyberbullying among young adults in Malaysia: The roles of gender, age and Internet frequency. Computers in Human Behavior, 46(I), I49-I 57. 
Baker, O. E., \& Tanrikulu, I. (2010). Psychological consequences o of cyberbullying experiences among Turkish secondary school children. Procedia Social and Behavioral Sciences, 2, 277I-2776.

Barlett, C.P., \& Chamberlin, K. (2017). Examining cyberbullying across the lifespan. Computers in Human Behavior, 7I, 444-449. doi: 10.1016/j.chb.2017.02.009.

Barton, A. L., Snider, J. B., Vazsonyi, A. T., \& Cox, J. L. (20I4). Adolescent religiosity as a mediator of the relationship between parentalreligiosity and adolescent health outcomes. Journal of Religion and Health, 53, 86-94. http://dx.doi.org/ I0.1007/s I0943012-9596-7.

Brailovskaia, J., Teismann, T., \& Margraf, J. (2018). Cyberbullying, positive mental health and suicide ideation/behavior Psychiatry Research, 267, 240-242.

Cappadocia, M.C., Craig, W.M., \& Pepler, D. (2013). Cyberbullying: prevalence, stability, and risk factors during adolescence. Can. J. Sch. Psychol. 28 (2), I7I-I 92.

Carone, D. A., \& Barone, D. F. (200I). A social cognitive perspective on religious beliefs: Their functionsand impact on coping and psychotherapy. Clinical Psychology Review, 2 I, 989-1003.

Casey, D. M., Williams, R. J., Mossière, A. M., Schopflocher, D.P., el-Guebaly, N., Hodgins, D. C., Smith, G. J., \& Wood, R. T. (20II). The role of family, religiosity, and behavior in adolescent gambling. Journal of Adolescence 34, 84I-85I. doi:10.1016/j.adolescence.2011.02.002.

Cotton, S., Larkin, E., Hoopes, A., Cromer, B. A., \& Rosenthal, S. L. (2005). The impact of adolescent spirituality on depressive symptoms and health risk behaviors. Journal of Adolescent Health, 36(6),529-537.

Davis, T. L., Kerr, B. A., \& Kurpius, S. E. R. (2003). Meaning, purpose, and religiosity in atrisk youth: Therelationship between anxiety and spirituality. Journal of Psychology \& Theology, 3 I (4), 356-365.

Debnam, K. J., Bradshaw, C. P., Milam, A. J., Mullen, M. M., \& Lacey, K. (20I7). The moderating role of spirituality in the association between stress and substance use among adolescents: Differences by gender. Journal of Youth Adolescence, DOI 10.1007/s 10964-017-0687-3.

Dutkova, K., Holubcikova, J., Kravcova, M., Babincak, P., Tavel, P., \& Geckova, A. M. (2017). Is spiritualwell-being among adolescents associated with a lower level of bullying behaviour? The mediatingeffect of perceived bullying behaviour of peers. Journal of Religion and Health, 56(6), 22I 2-222I.

Frankl, V. (1977). Man's search for Meaning: An Introduction to Logotherapy. London : Hodder \& Stoughton. 
Glock, C., Y., \& Stark, R. (1965). Religion and society in tension. Chicago: Rand McNally.

Gradinger, P.,Strohmeier, D., \& Spiel, C.(2009). Traditional bullying, andcyberbullying: Identification of risk groups for adjustment problems. Journal of Psychology, 2 I 7(4),205-2I3.

Graham, R., \&Wood Jr, F. R. (2018). Associations between cyberbullying victimization and deviant health risk behaviors. The Social Science Journal. Article in press.https://doi.org//0.1016/j.soscij.2018.05.005.

Greenfield, E. A., \& Marks, N. F. (2007). Religious Social Identity as an Explanatory Factor for Associations between More Frequent Formal Religious Participation and Psychological Well-Being. The International journal for the psychology of religion, 17(3), 245-259. https://doi.org//0.1080//05086/070/402309

Hirschi, T. (1969). Causes of delinquency. Berkeley, CA: University of California Press.

Horton, G. E., Luna, N., \& Malloy, T. (2016). Associations betweenspirituality, meaning in life, and depressive disorders among asample of individuals in treatment for substance-use disorders.Journal of Spirituality in Mental Health, 18(4), 283-299.

Kinanti, D. R., \& Hartati, N. (20I7). The effect of self esteem, social support, and religious orientation toward cyberbullying intention on adolescent at senior high school. Tazkiyah: Journal of Psychology,22(2), 191-202.

Koenig, H. G., Al Zaben, F., \& Khalifa, D. A. (20I2). Religion, spirituality and mental health in the Westand the Middle East. Asian Journal of Psychiatry, 5(2), 180-182.

Kowalski, R.M., Giumetti, G.W., Schroeder, A.N., \& Lattanner, M.R. (20/4). Bullying in the digital age: a Critical review and meta-analysis of cyberbullying research among youth. Psychol. Bul, 140 (4), I073-II 37.

Låftman, S.B., Modin, B., \& Östberg, V. (2013). Cyberbullying and subjective health: a large scale study of students in Stockholm, Sweden. Child Youth Serv. Rev, 35 (I), II 2-II9.

Landor, A., Simons, R. L., Gibbons, F. X., Simons, L. G., \& Brody, G. H. (20I I). The role of religiosity in the relationship between parents, peers, and adolescent risky sexual behavior. Journal of Youth Adolescence, 40, 296-309. DOI 10.1007/s 10964-010-9598.

Lee, C \& Shin, N. (2017). Prevalence of cyberbullying and predictors of cyberbullying perpetration among Korean adolescents. Computers in Human Behaviour, 68, 352-358.

Leung, A. N. M., Wong, N., \& Farver, J. M. (2018). Cyberbullying in Hong Kong Chinese students: Life satisfaction, and the moderating role of friendship qualities on cyberbullying victimization and perpetration. Personality and Individual Differences, I33, 7-12. doi:10.1016/j.paid.2017.07.016. 
McCullough, M. E., \& Willoughby, B. L. (2009). Religion, self-regulation, and self-control: Associations, explanations, and implications. Psychological Bulletin, 135, 69-93. http://dx.doi.org/10.1037/a0014213.

Pickering, L. E., \& Vazsonyi, A. T. (2010). Does family process mediate the effect of religiosity on adolescent deviance? Revisiting the notion of spuriousness. Criminal Justice and Behavior, 37, 97-I 18. http://dx.doi.org/I0.II77/00938548093478I3.

Pargament, K. I. (2007). The psychology of religion and coping: Theory, research, practice. New York: Guilford Press.

Peled, Y. (2019). Cyberbullying and its influence on academic, social, and emotional development of undergraduate students. Heliyon, 5, e0I393. doi: 10.1016/j.heliyon.2019.e01393.

Peter, I., \& Petermann, F. (20I8). Cyberbullying: A concept analysis of defining attributes and additional influencing factors. Computers in Human Behavior. doi:10.1016/j.chb.2018.05.013.

Pirutinsky, S. (20I4). Does religiousness increase self-control and reduce criminal behavior? A longitudinal analysis of adolescent offenders. Criminal Justice and Behavior, 4I, I2901307.

Safaria, T., \& Suyono, H. (2020). The role of parent-child relationship, school climate, happiness,and empathy to predict cyberbullying behavior. International Journal of Evaluation and Research in Education, 9(3), 548 557. DOI: I0.1 I591/ijere.v9i3.20299.

Safaria, T. (2016). Prevalence and impact of cyberbullying in a sample of indonesian junior high school students. The Turkish Online Journal of Educational Technology, I5(I), 82-9I.

Safaria, T. (20I5). Are daily spiritual experiences, self-esteem and family harmony predictors of cyberbullying among high school student?. International Journal of Research Studies in Psychology, 4(3), 23-34.

Sheldrake, P.,( 20I3)The new SCM dictionary of Christian Spirituality, SCM Press, London.

Sherkat, D. E., \& Ellison, C. G. (1999). Recent developments and current controversies in the sociology of religion. Annual Review of Sociology, 25, 363-394.

Sinha, M. (20/2). The relationship between the cyberbullying/cybervictmization and loneliness amongadolescents. Children and Youth Services Review, 34(4), 834-837.

Smith, C. (2003). Theorizing religious effects among American adolescents.Journal for the Scientific Study of Religion, 42, 17-30. http://dx.doi.org/10.1 I I I/1468-5906.t0I-I00158

Sung Hong, J., Ha Kim, D., Thornberg, R., Hyeok Kang, J., \& Morgan, J. T. (2018). 
Correlates of direct and indirect forms of cyberbullying victimization involving South Korean adolescents: An ecological perspective. Computers in Human Behavior, 87, 327-336.

Thoresen, C. E. (1998). Spirituality, health, and science: The coming revival? In S. Roth-Roemer, S. R. Kurpius, \& C. Carmin (Eds.), The emerging role of counseling psychology in health care (p. 409-43I). W W Norton \& Co.

Tokunaga, R. S. (2010). Following you home from school: A critical review and synthesis of research on cyberbullying victimization. Computers in Human Behavior, 26, 277-287.

VonDras, D. D., Schmitt, R. R., \& Marx, D. (2007). Associations between aspects of spiritual well-being,alcohol use, and related social-cognitions in female college students. Journal of Religion and Health, 46(4), 500-5I5.

Watts, L.K., Wagner, J., Velasquez, B., \& Behrens, P.I.. (2017). Cyberbullying in higher education: A literature review. Computers in Human Behavior 69, 268-274.

Willard, N. E. (2007). Cyberbullying and cyberthreats: Responding to the challenge of online social aggression, threats, and distress, IL: Research Press.

Wong, N., \& McBride, C. (20/8). Fun over conscience: Fun-seeking tendencies in cyberbullying perpetration. Computers in Human Behavior. doi: 10.1016/j.chb.2018.0

Yadav, M.,\& Yadav, R. (2018). Impact of spirituality/religiousness on cyber bullying and victimization in university students: Mediating effect of emotional intelligence. JournalReligion and Health.https://doi.org/I0.1007/s 10943-018-0637-8.

Zhou, Z., Tang, H., Tian, Y., Wei, H., Zhang, F., \& Morrison, C.M., (2013). Cyberbullying and its risk factors among Chinese high school students. Sch. Psychol. Int, 34 (6), 630-647.

Zych, I., Anna C. Baldry, A. C., David P. Farrington, D. P., \& Vicente J. Llorent, V. J. (2017).Are children involved in cyberbullying low on empathy? A systematic review and meta-analysis of research on empathy versus different cyberbullying roles. Aggression and Violent Behavior. doi:10.1016/j.avb.2018.03.004.

Zych, I., Ortega-Ruiz, R., \& Del Rey, R. (20I5). Systematic review of theoretical studies on bullying and cyberbullying: Facts, knowledge, prevention, and intervention. Aggression and Violent Behavior, 23, I-2I. 